\title{
Evaluations of some trace metal levels from the leaves of Salix nigra in Hayatabad industrial estate Peshawar, Khyber Pakhtunkhwa Pakistan
}

\author{
Wasim Ahmed ${ }^{1, ~ *, ~ M u s h t a q ~ A h m a d ~}{ }^{1}$, Abdur Rauf ${ }^{2}$, Faridullah Shah ${ }^{3}$, Sajjad Khan ${ }^{1}$, Sajid Kamal ${ }^{1}$, \\ Shahzaib Shah ${ }^{1}$, Abdullah Khan ${ }^{1}$ \\ ${ }^{1}$ Department of Bio-Technology, Faculty of Biological Sciences, University of Science \& Technology Bannu, KPK, Pakistan \\ ${ }^{2}$ Centre for Phytomedicine and Medicinal Organic Chemistry, Institute of Chemical Sciences, University of Peshawar, Peshawar, Pakistan \\ ${ }^{3}$ Department of Bio-Chemistry \& Community Medicine, Bannu Medical College Bannu, KPK, Pakistan
}

\author{
Email address: \\ waseem_bnu57@yahoo.com (W. Ahmed)
}

\section{To cite this article:}

Wasim Ahmed, Mushtaq Ahmad, Abdur Rauf, Faridullah Shah, Sajjad Khan, Sajid Kamal, Shahzaib Shah, Abdullah Khan. Evaluations of Some Trace Metal Levels from the Leaves of Salix nigra in Hayatabad Industrial Estate Peshawar, Khyber Pakhtunkhwa Pakistan. American Journal of Biomedical and Life Sciences. Special Issue: Phytochemical and Pharmacological Study of Medicinal Plants.

Vol. 3, No. 2-1, 2015, pp. 21-24. doi: 10.11648/j.ajbls.s.2015030201.13

\begin{abstract}
Plants are crucial components of eco and agrosystems \& are the first compartment of the telluric food chain. When grown-up on contaminated soils, they become latent threat to human and animal fitness as they may gather some toxic elements (e.g., metals) in their tissues and causing many serious problems. A new preliminary draft report by "ArizonaSkyWatch" shows dramatic increases in heavy metals that simply do not belong in our air. These figures indicate how many times they are over the allowable toxic limit: $\mathrm{Cd} 6.0, \mathrm{Cr} 6.4 \& \mathrm{Zn} 7.5$. The current study was aimed to evaluate chromium, zinc and cadmium in the leaves of Salix nigra using atomic absorption spectrometry (UV-750 Spectrophotometer). The results showed higher concentration of chromium in $S$. nigra $(0.079 \mathrm{mg} / \mathrm{Kg})$. Zinc and cadmium were with values of 0.55 and $0.04 \mathrm{mg} / \mathrm{kg}$. The chromium levels in the leaves of $S$. nigra falls above the acceptable limits whereas zinc content exceeds the FAO/WHO set limits which are $(99.4$ and $0.20 \mathrm{mg} / \mathrm{kg})$. The sturdy connection between the degree of contamination and concentrations in all plant leaves displayed the results that the leaves of $S$. nigra imitate the environmental changes accurately, and that they seem as an effective biomonitor of environmental quality in areas subjected to industrial and traffic pollutions.
\end{abstract}

Keywords: Salix nigra, Trace metals, Industrial pollution, Traffic pollution

\section{Introduction}

Although there is no clear definition of what a heavy metal is, density is thought to be the defining feature in many cases. Heavy metals are thus can be explained or defined as, those metals having a specific density of $5 \mathrm{~g} / \mathrm{cm}^{3}$ or more than this. In routine, the term is usually used for common transition metals, such as lead, copper and zinc etc. 1817 was the year when the term "Heavy metal" was first introduced. This was the time when Gmelin reported a classification of elements. Gmelin classified the elements into light metals, heavy metals and non-metals. Heavy metals are a cause of environmental pollution (heavy metal pollution) or contamination from a number of sources. These sources include petrol contaminated with lead; waste material resulted from industrial activities and contamination of metal ions from the soil into lakes and rivers as a result of acid rain.

Heavy metals are natural machinery of the environment but remained matter of great concern because they are being added to soil, water and air in escalating amount because of a rapid increase in population as well as expansion of industrial activities, etc. [1]. Most of the living organisms depend on heavy metals for their survival, but it should also be noted that the excessive amount of these heavy metals is generally detrimental to plants and animals. Although adverse health effects of heavy metals have been reported, in some areas exposure to heavy metals is still experienced. For example, mercury is a source in gold mining in many parts of Latin America till now. Arsenic is still common in wood preservatives, and tetraethyl lead is used to be a common additive to petrol, although the developed countries have 
reduced its use. The poison of heavy metals depends largely on their chemical forms, concentration, residence time, etc [2-4]. In the present era, heavy metal pollution is a serious peril to the earth's atmosphere. Traffic emissions on roads make one of the main causes of heavy metals accumulation in the environment and in plant species [5-8]. Heavy metals released during industrial actions forms the major part of the contamination that accumulates in air, soil and water bodies. Chromium is a particular case which exerts toxic effect on biological systems arising from the possibility of free diffusion across cell membrane and its strong oxidative potentials [9]. Zinc induces harm to living systems as indispensable enzymes are involved in metabolism [10]. Photosynthesis is one of the major physiological processes which is identified to be affected severely by heavy metals. Heavy metals cause damage to the photosynthetic apparatus which further induces changes in photosynthetic electron transport and carbon fixation capacity [11-13]. Cadmium for example, enters the air from mining industries and burning of coal as well as through domestic wastes. Cadmium particles in air can journey long distances before entering into water bodies. Cadmium occurs naturally in ores in combination with zinc, lead and copper. Cadmium compounds works as stabilizers in the products made of from PVC, color pigment and now a days most commonly, in nickel cadmium batteries which are rechargeable. 20th century is the era during which the cadmium emissions increased rapidly, one reason behind that is cadmium-containing products are re-cycled rarely and most often dumped together with household waste. Another major source of cadmium exposure is cigarette smoking. In non-smokers, food plays a vital role in cadmium exposure. Recent investigations revealed that adverse health effects of cadmium exposure may occur at lower exposure levels than previously estimated, resulting primarily in kidney damage and possibly in bone effects and fractures.

The toxicity of cadmium, chromium and zinc ions and their bindery mixture have been studied at varying test level using duckweed (Stemless aquatic plants of the family, Lemnaceae) as the test organism. Chromium causes cancer and stomach ulcer. Chromium might lower blood sugar levels too much if taken along with diabetic medications. There are three reports of liver and kidney damage in patients who took chromium. It might affect brain chemistry and might make behavioral or psychiatric conditions worse. Zinc is a trace element that is essential for human health. Loss of appetite, decreased sense of taste and smell, slow wound healing and skin sores are being resulted from decreased absorption of Zinc. Birth defects may also be reported due to Zinc deficiency in the body. Although humans can tolerate comparably large amounts of zinc, too much zinc can still cause renowned health problems, such as stomach cramps, skin irritations, vomiting, nausea and anaemia. Colossal levels of zinc can mutilate the pancreas and disturb the protein metabolism, and causes arteriosclerosis. In the work place environment, zinc contagion can lead to a flu-like condition known as metal fever. This condition passes after two days and is caused by over sensitivity. Zinc can be a danger to unborn and newborn children. When their mothers have absorbed large concentrations of zinc the children may be exposed to it through blood or milk of their mothers. Zinc causes ataxia and lethargy. Some elements regarded as heavy metals are essential, in small quantities, for human health including vanadium, manganese, copper, zinc, selenium, strontium iron, cobalt, and molybdenum [14]. A deficiency of these essential metals may increase susceptibility to heavy metal poisoning. Medicinal herbs are effortlessly contaminated during growth, development and processing. After collection and transformation into useable form, the heavy metals confined in plants finally enter the human body and may distract the normal functions of central nervous system, liver, lungs, heart, kidneys and brain, leading to hypertension, abdominal discomfort, skin eruptions, intestinal ulcer and different types of cancers .In current investigation, chromium, zinc and cadmium concentration was identified in the leaves of Salix nigra using atomic absorption spectrometry.

\section{Materials and Methods}

\subsection{Sampling}

Fresh leaves of Salix nigra plant were collected within the study area (Industrial Estate, Jumrod road Peshawar, Pakistan). The plant was properly identified by Prof. Dr. Abdur Rashid, Department of Botany, university of Peshawar. The plant material was washed in fresh running water to eliminate dust, dirt and possible parasites and then treated with double ionized water. The samples were shade-dried for 4 weeks at $25-30^{\circ} \mathrm{C}$. During this sample processing, necessary measures were taken in order to avoid any loss or contamination of heavy metals. Upon completely dried, the leaves were milled to fine powder for the desired activity using a local grinding machine. The fine powder obtained then used at different intervals during our study.

\subsection{Reagents}

All reagents used were of analytical grade. All the plastic and glassware were cleaned by drenching them into a $10 \%$ nitric acid solution and rinsing them with distilled water prior to use. Trioxonitrate (V) and tetraoxochlorate (VII) acids were used as reagents for the evaluation of our study.

\subsection{Digestion}

The samples were digested according to the standard procedure described by Awofolu, (2005) [15] using trioxonitrate (V) and tetraoxochlorate (VII) acids. Blank solution was prepared using $5 \mathrm{~mL}$ trioxonitrate (V) acid. The results of the spectrophotometery are shown in table 1 .

\subsection{Analysis}

The digests were run on the atomic absorption spectrophotometer (Cole UV-750) and noted the readings. Three replicate digestions were carried out for sample. 
Results obtained by the spectrophotometery are given in the following in table 1 .

Table 1. The dry weight trace metal contents $(\mathrm{mg} / \mathrm{kg})$ in leaves of S. Nigra in Hayatabad Industrial Estate, Peshawar.

\begin{tabular}{llll}
\hline & \multicolumn{4}{l}{ TRACE METALS (mg/kg) } \\
\hline Salix nigra Leaf Sample & $\mathrm{Zn}$ & $\mathrm{Cr}$ & $\mathrm{Cd}$ \\
Replicate 1 & 0.50 & 0.080 & 0.04 \\
Replicate 2 & 0.55 & 0.072 & 0.05 \\
Replicate 3 & 0.60 & 0.085 & 0.04 \\
\hline
\end{tabular}

\section{Results and Discussion}

Concentration of essential and non-essential heavy metals in medicinal plants beyond allowable limit is a matter of great concern to public safety all over the world. The problem is rather more somber in Pakistan, because medicinal plants which form the raw materials for the finished products are neither controlled nor properly regulated by quality assurance parameters.

Confrontation of willows to some metals $(\mathrm{Cd}, \mathrm{Cu}, \mathrm{Zn}, \mathrm{Ni}$, $\mathrm{Pb}, \& \mathrm{Fe})$ and its capacity to accumulate momentous amounts of metal in plant tissues had been documented and suggested its possible use for metal extraction $[16,21]$. The studies reveal much potential for decontamination of cadmium $[22,26]$. While Salix should be defined as high accumulator of metal rather than a more efficient hyperaccumulator as are a few herbaceous plants, there is an essential advantage of Salix over herbaceous species for use in phytoextraction. Herbaceous hyperaccumulator have shallow root systems, but willows are recommended for deeper soil contamination. A combination of high metal concentrations in tissues, extensive root system, perennial habit and high biomass results in high potential for removal of significant amounts of $\mathrm{Cd}$ at stem harvest [27, 29]. Although resistance to heavy metals has been well documented for Salix, a biochemical mechanism for metal tolerance is yet to be investigated. There are some evidences which show that metal tolerance in Salix may be credited to the synthesis of phytochelatin. Different species of willow, as well as some clones, vary considerably in their metal translocation patterns and their ultimate resistance to heavy metals. Salix is currently under intensive research analysis for its potential for soil phytoremediation, the plants' ability to clean substrates through chemical and metabolic processes. Those include phytoextraction (the removal of heavy metals from soil due to the plants' uptake and translocation of metals into above ground organs), phytodegradation (the accumulation and biochemical transformation of organic pollutants by plants and associated microorganisms), rhizofiltration and rhizostimulation (the removal of pollutants from aqueous solutions through direct uptake by plants roots) and phytostabilization (substrate dehydration and prevention of pollutant transport). Tables 1 display the dry-weight trace metal contents $(\mathrm{mg} / \mathrm{kg})$ in the leaves of $S$. nigra of the study area. Chromium is present in appreciable amount in all samples.

\section{Conclusion}

The results of this study indicate the pollution tendencies of this plant within the area under study, which might also result in the exposure of consumers to a great health risk. The chromium levels in the leaves of $S$. nigra fall above the acceptable limits whereas zinc content exceeds the FAO/WHO set limits. The sturdy connection between the degree of contamination and concentrations in plant leaves displayed the results that the leaves of $S$. nigra imitate the environmental changes accurately, and that they seem as an effective biomonitor of environmental quality in areas subjected to industrial and traffic pollutions.

\section{Acknowledgements}

We would like to express our warm gratitude to our colleagues in department of Chemistry, University of Peshawar, Peshawar, KPK-Pakistan for their support and kind help during the entire process of samples analysis. We are also thankful to our fellows in NIFA, Tarnaab-Peshawar, Pakistan for their technical assistance during the study.

\section{References}

[1] Aksoy, A., Sahin, U., Duman, F.,Robinia (2000). Pseudoacacai L. as a possible bio-Monitor of heavy metal Pollution in Kayseri. Turk. J. Bot: 24(5):279-284.

[2] WHO (1972). Health Hazard of Human Environment Geneva.

[3] Schuberk, J (1973). Heavy metals - toxicity and environmental pollution. In: Metal Ions in Biological Systems,Dhar, S. K (ed). Plenum Press, New York. 376.

[4] Mielk,HW.,Reagon, PL (1988). Soil as an impact pathway of human lead exposure. Environ. Health Perspect. 106(1):217229 .

[5] Ward,NI., Brooks, R.R., Reeves, R.D (1974). Effect of Lead from motor vehicle exhaustion on tree along a major through Fare in palmerston North, New Zealand. Environ. Pollution 6:149-158

[6] Grodzinka, K (1977). Acidity of tree bark as a bio-indicator of forest pollution in Southern Poland: Water, Air and Soil Pollution 8:3-7.

[7] Momani, K., Jiries, A., Jaradat, Q (2000). Atmospheric deposition of $\mathrm{Pb}, \mathrm{Zn}, \mathrm{Cu}$ and $\mathrm{Cd}$ in Amman. Jordan. Turk. J. Chem. 24:231-237.

[8] Scerbo R, Possenti L, Lampugnani L, Ristori T, Barale R, Barghigiani C (2002). Lichen (xanthoriaparientina) biomonitoring of trace element contamination and air quality assessment in Livorno province (Tuscany, Italy). Sci. Total Environ. 286(1-3):27-40

[9] Shanker, A.K., Cervantes, C., Loza-Tavera, H., Avudainayagam, S (2005). Chromium Toxicity in plants. Environ. Int. 31(5):739-753.

[10] Momani, K., Jiries, A., Jaradat, Q (2000). Atmospheric deposition of $\mathrm{Pb}, \mathrm{Zn}, \mathrm{Cu}$ and $\mathrm{Cd}$ in Amman. Jordan. Turk. J. Chem. 24:231-237. 
[11] Van, A.F., Clijsters, H (1985). Inhibition of Photosynthesis in Phaseolus Vulgaris by treatment with toxic concentration of Zinc: Effect of ribulose- 1,5 - bio-phosphate Carboxylase/Oxygenase. J. Plant Physiol. 125:355-360

[12] Krupa, Z., Baszynski, T (1995). Some aspects of heavy metal toxicity towards photosynthetic apparatus - Direct and indirect effects on light and dark reactions.Acta Physiology of Plants. 17:177-190.

[13] Sersen, F., Kralova, K., Bumbalova, A (1998). Action of Mercury on the photosynthesic apparatus of spinach chloroplasts.Photosynthetica 35:551-559.

[14] Bánfalvi, G (2011), Heavy Metals, Trace Elements and their Cellular Effects', in G Bánfalvi (ed.),Cellular Effects of Heavy Metals, Springer, Dordrecht, pp. 3-28, ISBN 9789400704275

[15] Awofolu, O.R (2005). A Survey of Trace Metals in Vegetation, Soil and lower Animals along some selected major road in metropolitan city ofLagos. Environ. Monitoring Assessment 105:431-447.

[16] Punshon, T., Dickinson, N(1997). Acclimation of Salix to metal stress', New Phytologist 137, 303-314.

[17] Ali, M.B., Tripathi, R. D., Rai, U. N., Pal, A. and Singh, S.P(1999). Physico-chemical characteristics and pollution level of lakeNainital (U.P., India): Role of macrophytes and phytoplankton in biomonitoring and phytoremediation of toxic metal ions, Chemosphere 39(12), 2171-2182.

[18] Watson, C., Pulford, I. D., Riddell-Black, D (2003). Development of a hydroponic screening technique to assess heavy metal resistance in willow (Salix), Int. J. Phytoremediat. 5(4), 333-349.

[19] Ali, M. B., Vajpayee, P., Tripathi, R. D., Rai, U. N., Singh, S. N. and Singh, S. P (2003). 'Phytoremediation of Lead, Nikel, and Copper by Salix acmophyllaBoiss.: Role of antioxidant enzymes and antioxidant substances', Bull. Environ. Contam.Toxicol. 70, 462-469.
[20] Keller, C., Hammer, D., Kayser, A., Richner, W., Brodbeck, M and Sennhauser, M (2003). 'Root development and heavy metal phytoextraction efficiency: Comparison of different plant species in the field', Plant Soil 249, 67-81.

[21] Kuzovkina, Y. A., Knee, M. and Quigley, M. F (2004b). 'Cadmium and copper uptake and translocation of five Salix L. species', Int. J. Phytoremed., in press.

[22] Dickinson, N.M., Punshon, T., Hodkinson, R. B., Lepp, N.W (1994). 'Metal tolerance and accumulation in willows', in P. Aronsson and K. Perttu (eds), Willow Vegetation Filters for Municipal Wastewater and Sludges, Swedish University of Agricultural Sciences, Uppsala, pp. 121- 127.

[23] Landberg, T., Greger, M (1994). 'Cadmiun tolerance in Salix', BiologiaPlantarum 361(Suppl.), 280.

[24] Greger, M., Landberg, T(1999).'Use of willow in phytoextraction', Int. J. Phytoremed. 1(2), 115-123.

[25] Robinson, B. H., Mills, T. M., Petit, D., Fung, L. E., Green, S. R. and Clothier, B. E(2000). 'Natural and induced cadmiumaccumulation in poplar and willow: Implications for phytoremediation', Plant Soil 227, 301-306.

[26] Klang-Westin, E., Perttu, K (2002).'Effect of nutrient supply and soil cadmium concentration on cadmium removal by willow', Biomass Bioenerg. 23, 415-426.

[27] Keller, C., Hammer, D., Kayser, A., Richner, W., Brodbeck, M., Sennhauser, M(2003). 'Root development and heavy metal phytoextraction efficiency: Comparison of different plant species in the field', Plant Soil 249, 67-81.

[28] Klang-Westin, E., Eriksson, J (2003). 'Potential of Salix as phytoextractor for $\mathrm{Cd}$ on moderately contaminated soils', Plant Soil 249, 127-137.

[29] Lunackova, L., Masarovicova, E., Kral'ova, K., Stresko, V (2003). 'Response of fast growing woody plants from family Salicaceae to cadmium treatment', Bull. Environ. Contam.Toxicol. 70, 576-585. 